\title{
GLOBALISATION AND ITS IMPACT ON INDIAN RURAL AGRICULTURE FOR SUSTAINABLE DEVELOPMENT
}

\author{
Ms. Rashi Saxena, \\ Assistant Professor, \\ STEP-HBTI, Kanpur \\ rash_saxena@rediffmail.com
}

\begin{abstract}
This paper is deals with a basically a globalization and its impact on the Indian Rural agriculture for the sustainable development in India, the globalization is the process began in1991as a result of new economic policies. The main feature of this economy is that it work at central level and the states have the right to make changes in the central policy depending on their requirements, and they are responsible for making it work. Thus the new system has changed from command economy to federal economy. Globalization eludes to builds the development of money, inputs, yields, data and science crosswise over inconceivable geographic ranges.
\end{abstract}

Keywords:_Agriculture, Economy, Globalization, Production system, Development, Rural Marketing.

Introduction: The Common Meaning of Globalization is to treat the whole world as one village. The Concept Of global Village is not a concept. Today the social economic Culture ion and political relation have crossed all national boundaries. This increasing self-dependence of the world can be called global commercialization or away. The people of many developing countries like India are feeling the adverse effect of increasing globalization in terms of livelihood and employment. The rural farmers are affected by the rise and fall of world markets and the storm of globalization is threatening to sweep the Indian culture. Today the Indian Rural market is full of foreign goods. According to one estimates there are about 4600 foreign companies selling cosmetics, soft drinks, fast foods and electronic goods. They have even claiming patent rights on Indian plants and trees by producing the seeds. The globalization is a wide and comprehensive economic process whose scope spreads countries and societies of the overall the counties and societies of the world. Globalization is the process of integration of the world economics in condition of free markets, which includes free flow of trade and capital and movement of persons across national borders.

\section{Objectives:}

1. To encourage foreign investment and foreign trade to increase foreign currency reserves.

2. 2. To establish payment balance

3. To increase Production system.

4. To give opportunities to industrialists and encourage foreign Industrialists to start new companies.

\section{Basis of globalization Programme:}

Foreign trade (Import and export) 
To foreign company can get license through an indigenous company to do trade on production.

Assembling or making things from imported parts in another country.

Companies of two countries enter joint ventures.

Two countries enter trade

It was imperative for all member states to sign rural agriculture treaty on first January 1995. This treaty had following condition that would be applicable from first January 2000. According to rural market approach to the treaty all non - taxable restriction have converted in to taxable restriction. According to commitments of export competition, all developed countries have to reduce export competition. The domestics help for farmers is connected with state help in the production process.

India's Agriculture Strategy with regard to international Agriculture Trade

What should be India's Strategy especially when it has lifted all types of quantitative bans on 1429 products. India should not bother about the annoyance of the developed countries like the European union and united states of America And organize developing countries and ask for reduction of duty and subsidies in their countries. The Indian government is determined to save domestic agriculture from foreign competition and is giving protection to it in appropriate measure decided by WTO. In April 2000 after the quantitative ban was lifted there was a marked increase in exports of ketchup, fruits, meat etc. however it forms a very small portion of the exports. And the hopes of increase exports by liberalization have proved false. No wonder the value of agriculture exports fell to 1.8 million dollars in 200-01 from 2.8 million dollars in19992000 .

\section{Globalization in India-Evaluation}

Globalization has brought rapid changes at the international level. Due to the sophisticated means of communication and new technology many things like production, ideas, working methods and other things are fast becoming obsolete. The process of globalization is taking the developing countries in its grip. It tends to strengthen international financial organization so that they can interfere in the affairs of these countries. The process of globalization influences economy, communication, politics and culture. All these things have become more interconnected in the whole world and the culture of universalization is spreading all around us.

In India the growth rate was never more than $6 \%$ in 1990 decade. Before that the average growth rate was only $3 \%$. In the decade of 1990, the situation was stable which was conducive to experiments with policies of liberalization, globalization, economic reforms and new experiments. At this time our foreign exchange reserves were close to zero. Now we have almost 120 lakh dollars as foreign exchange reserves. Some states 
Asia Pacific Journals

benefited from these polices of 1990 but other states like Bihar, Orissa, Chhattisgarh, Jharkhand, etc have not been able to adjust to these reforms. That is why there is no development in states nor has poverty decreased. The end result is that globalization has helped multinational companies more than the poor population of India.

Conclusion: The government should make policies that benefit all the farmers equally, especially the landless farmers and agriculture labour. The government should make all efforts to create scientific awareness among farmers so that they can withstand the international competition. There is need for technological development land reforms, use of hybrid pesticides, fertilizers and irrigation facilities. The government should try and focus on these problem areas so that can the impact of globalization is favorable for India agriculture. We cannot afford to export agriculture products at low rates so we must bend our policies according to WTO and benefit our farmers, we need to prepare a draft of strategies on the basis the strategies of developed countries.

\section{REFERENCES:}

[1] "Improvement of the situation of women in rural Areas", General Assembly, United Nations-2005.

[2] "The impact of globalization on families and communities", International Anglican Family Networks, London-2008.

[3] Sandhya Rani, G. "Globalization and Women", Asia- Pacific Journal of Social Sciences-2010,
[4] Palaniturai,G., Ramesh,R. "Globalization and Rural Development”, New Delhi, 2010.

[5] Rahaman, Md. Mizanur. "Impact of globalization on rural development", Thailand-2013.

[6] Chandran, Jayprakash, Shankar, R. "Emerging urban development issues in the context of globalization",

[7] Institute of Town Planners", India Journal, 2009.

[8] Ashutosh, Kumar "Effect of globalization on Indian society", 2013.

[9] Shaikh, Ziya. "Impact of globalization social and cultural values in India"

[10] Wheelan, Simon. "The impact of globalization on urban development", ICFI-1999.

[11] Gyamisho, Pema. "The impact of globalization on rural development with a particular focus on mountain area",

[12] ICIMOD, Nepal.

[13] Pais, Shobha. "Globalization and its impact on families", 2006.

[14] http://www.ukessays.com 